\title{
Bcl-2-Modifying Factor
}

National Cancer Institute

\section{Source}

National Cancer Institute. BCl-2-Modifying Factor. NCI Thesaurus. Code C104160.

Bcl-2-modifying factor (184 aa, $\sim 21 \mathrm{kDa}$ ) is encoded by the human BMF gene. This protein plays a role in the positive regulation of pro-apoptotic gene products. 